МРНТИ 27.31.15, 29.05.03

УДК 517.957, 532.5

https://doi.org/10.51889/2020-4.1728-7901.09

\title{
TWO-DIMENSIONAL NONLOCAL NONLINEAR SCHRODINGER EQUATION BASED ON THE ABLOWITZ-MUSSLIMANI SYMMETRY CONDITION
}

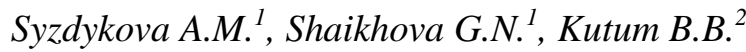 \\ ${ }^{1}$ L.N. Gumilyov Eurasian National University, Nur-Sultan, Kazakhstan \\ ${ }^{2}$ E.A. Buketov Karaganda State University, Karaganda, Kazakhstan
}

\begin{abstract}
The nonlinear Schrodinger equation is a nonlinear partial differential equation and integrable equation that play an essential role in many branches of physics as nonrelativistic quantum mechanics, acoustics, and optics. In this work, motivated by the ideas of Ablowitz and Musslimani, we successfully obtain a two-dimensional nonlocal nonlinear Schrodinger equation where the nonlocality consists of reverse time fields as factors in the nonlinear terms. The nonlocal nonlinear Schrodinger equation admits a great number of good properties that the classical nonlinear Schrodinger equation possesses, e.g. PT-symmetric, admitting Lax-pair, and infinitely many conservation laws. We apply the Darboux transformation method to the two-dimensional nonlinear Schrodinger equation.

The idea of this method is having a Lax representation, one can obtain various kinds of solutions of the Nth order with a spectral parameter. The exact solutions and graphical representation of obtained solutions are derived.
\end{abstract}

Keywords: Darboux transformation, Schrodinger equation, symmetry, nonlocal, Ablowitz- Musslimani.

\author{
Аң̧датna \\ А.М. Сыздыкова ${ }^{1}$, Г.Н. Шайхова, Б.Б. Кутумм ${ }^{2}$ \\ ${ }^{1}$ Л.Н. Гумилев атындавы Еуразия ұлттық университеті, Нұр-Сұлтан қ., Қазақстан \\ ${ }^{3}$ E.А. Букетов атындавы Қараванды мемлекеттік университеті, Караванды қ.., Қазақстан

\section{АБЛОВИЦ-МУСЛИМАНИ СИММЕТРИЯ ШАРТЫНА НЕГІЗДЕЛГЕН ЕКІ ӨЛШЕМДІ ЛОКАЛЬДЫ ЕМЕС СЫЗЫҚТЫ ЕМЕС ШРЕДИНГЕР ТЕНДЕУІ}

Сызықты емес Шредингер теңдеуі - бұл релятивистік кванттық механика, акустика және оптика сияқты физиканың көптеген салаларында маңызды рөл атқаратын сызықтық емес дербес дифференциалды және интегралданатын теңдеу. Бұл мақалада Абловиц-Мусслимани идеяларын негізге ала отырып, екі өлшемді локальды емес сызықты емес Шредингер теңдеуі шығарылды, мұндағы локальды емес ол сызықты емес мүшелердегі кері уақыт өрістерінен тұрады. Локальды емес сызықты емес Шредингер теңдеуі, классикалық сызықты емес Шредингер теңдеуіне ие көптеген жақсы қасиеттерді қабылдайды мысалы: РТ-симметриясы, Лакс жұбы және шексіз көптеген сақталу заңдары. Екі өлшемді сызықты емес Шредингер теңдеуіне Дарбу түрлендіру әдісі қолданылды.

Бұл әдістің негізіндегі Лакс ұсынысы спектрлік параметрмен $\mathrm{N}$-ші типті шешімдердің әртүрін алуға мүмкіндік береді. Екі өлшемді локальды емес сызықты емес Шредингер тендеуінің нақты шешімдері алынды. Сонымен қатар, әртүрлі параметрлердің көмегімен алынған шешімдердің графикалық көрінісі тұрғызылды.

Түйін сөздер: Дарбу түрлендіруі, Шредингер теңдеуі, симметрия, локальды емес, Абловиц-Муслимани.

\author{
Аннотачия \\ А.М. Сыздыкова ${ }^{1}$, Г.Н. Шайхова ${ }^{1}$, Б.Б. Кутум ${ }^{2}$ \\ ${ }^{1}$ Евразийский начиональный университет имени Л.Н. Гумилева, г. Нур-Султан, Казахстан \\ ${ }^{3}$ Карагандинский государственный университет имени Е.А. Букетова, г. Караганда, Казахстан \\ ДВУМЕРНОЕ НЕЛОКАЛЬНОЕ НЕЛИНЕЙНОЕ УРАВНЕНИЕ ШРЕДИНГЕРА НА ОСНОВЕ \\ УСЛОВИЯ СИММЕТРИИ АБЛОВИЦА-МУСЛИМАНИ
}

Нелинейное уравнение Шредингера - это нелинейное уравнение в частных производных и интегрируемое уравнение, которое играет важную роль во многих разделах физики, таких как нерелятивистская квантовая механика, акустика и оптика. В работе, основываясь на идее Абловица и Мусслимани, получено двумерное нелокальное нелинейное уравнение Шредингера, в котором нелокальность состоит из обратных полей времени в нелинейных членах. Нелокальное нелинейное уравнение Шредингера допускает множество хороших свойств, которыми обладает классическое нелинейное уравнение Шредингера, например РТ-симметрию, пару Лакса и бесконечное множество законов сохранения. Применен метод Дарбу преобразования к двумерному нелинейному уравнению Шредингера. 
Идея этого метода состоит в том, что представление Лакса позволяет получать различные виды решений Nго порядка со спектральным параметром. Получены точные решения и графическое представление полученных решений.

Ключевые слова: преобразование Дарбу, уравнение Шредингера, симметрия, нелокальность, АбловицМуслимани.

\section{Introduction}

Nonlinear integrable equations exist in all aspects of scientific research and play an important role in physics. There are numerous nonlinear integrable equations that are applied to lattice dynamics, fluid mechanics, elasticity, electromagnetics, etc [1-4]. For example, the Korteweg-de Vries equation describes the evolution of weakly dispersive and small amplitude waves in quadratic and cubic nonlinear media, respectively $[3,4]$. The integrable cubic nonlinear Schrodinger equation which is well-known for its application to the evolution of weakly nonlinear and quasi-monochromatic wave trains in media with cubic nonlinearities $[3,4]$. In order to solve these equations, many research, and effective methods have been produced, such as Darboux transformation [5-7], the Hirota bilinear method [2], and inverse scattering transform (IST) [3,4]. However, there is a special kind of equation called nonlocal equation among many nonlinear integrable equations [8-14]. As the name suggests, nonlinear integrable nonlocal equation refers to the nonlinear integrable evolution equation with the nonlocal nonlinear term, for example, $q^{*}(x, t)$ is replaced by $q^{*}(-x,-t), q^{*}(x,-t)$, or $q^{*}(-x, t)$. In this work, we study the two-dimensional nonlocal nonlinear Schrodinger (NLS) equations where the nonlocality consists of reverse time fields

$$
\begin{aligned}
& i q_{t}(x, y, t)+q_{x y}(x, y, t)-v(x, y, t) q(x, y, t)=0, \\
& v_{x}(x, y, t)+2\left(q(x, y, t) q^{*}(x, y,-t)\right)_{y}=0,
\end{aligned}
$$

where * means a complex conjugate, $q(x, y, t)$ is complex function, $v(x, y, t)$ is real function. System (1)(2) is called T- symmetric because is invariant under the action if the PT operator, i.e. the joint transformation $t \rightarrow-t$. We apply the Darboux transformation which is a powerful tool to solve integrable equations.

\section{Darboux transformation}

In this section, we construct the Darboux transformation for the two-dimensional nonlocal NLS equation, and then we derive its exact solutions. Equations (1)-(2) are yielded by the integrability condition of the following spectral equations

$$
\begin{aligned}
& \Psi_{x}=A \Psi, \\
& \Psi_{t}=2 \lambda \Psi_{y}+B \Psi,
\end{aligned}
$$

where the matrices $A$ and $B$ are given by

$$
\begin{gathered}
A=-i \lambda \sigma_{3}+A_{0}, \\
B=-\frac{1}{2} i v(x, y, t) \sigma_{3}+i\left(\begin{array}{cc}
0 & q_{y}(x, y, t) \\
-q_{y}^{*}(x, y,-t) & 0
\end{array}\right),
\end{gathered}
$$

with

$$
A_{0}=\left(\begin{array}{cc}
0 & q(x, y, t) \\
-q^{*}(x, y,-t) & 0
\end{array}\right), \sigma_{3}=\left(\begin{array}{cc}
1 & 0 \\
0 & -1
\end{array}\right) \text {. }
$$

The gauge transformation with nonsingular matrix $M=\left(m_{j k}(x, t, \lambda)\right)_{2 \times 2}(k=1,2)$

$$
\Psi^{[1]}=T \Psi=(\lambda I-M) \Psi .
$$

Changes the spectral problem (3)-(4) into new one 


$$
\begin{aligned}
& \Psi_{x}^{[1]}=A^{[1]} \Psi^{[1]}, \\
& \Psi_{t}^{[1]}=2 \lambda \Psi_{y}^{[1]}+B^{[1]} \Psi^{[1]},
\end{aligned}
$$

where $A^{[1]}$ and $B^{[1]}$ depend on $q^{[1]}, v^{[1]}$ and $\lambda$.

The relation between $q^{\left[{ }^{[1]}\right.}, v^{[1]}$ and $A^{[1]}-B^{[1]}$ is the same as the relation between $q, v$ and $A-B$. It is obvious that Darboux matrix $T$ satisfies equations

$$
\begin{aligned}
& T_{x}+T A=A^{[1]} T, \\
& T_{t}+T B=2 \lambda T_{y}+B^{[1]} T .
\end{aligned}
$$

By direct computation based on equations (11)-(12), we can obtain a relation between potential functions $q^{[1]}$ and $q$ :

$$
\begin{aligned}
& q^{[1]}(x, y, t)=q(x, y, t)-2 i m_{12}, \\
& q^{*[1]}(x, y,-t)=q^{*}(x, y,-t)-2 i m_{21}, \\
& v^{[1]}=v+4 i m_{11 y}=v-4 i m_{22 y} .
\end{aligned}
$$

with a constraint $m_{12}=-m_{21}^{*}(x, y,-t)$. By setting

$$
M=H \Lambda H^{-1},
$$

with

$$
H=\left(\begin{array}{ll}
f_{1} & g_{1} \\
f_{2} & g_{2}
\end{array}\right), \Lambda=\left(\begin{array}{ll}
\lambda_{1} & 0 \\
0 & \lambda_{2}
\end{array}\right) .
$$

where $\left(f_{1}, f_{2}\right)^{T}=\left(\psi_{1}(x, y, t), \psi_{2}(x, y, t)\right)^{T}$ is a solution to equation (3)-(4) with $\lambda=\lambda_{1}$ and $\left(g_{1}, g_{2}\right)^{T}=$ $\left(\psi_{2}^{*}(x, y,-t), \psi_{1}^{*}(x, y,-t)\right)^{T}$ is the solution when $\lambda=-\lambda_{1}^{*}=\lambda_{2}$, we can obtain the explicit expression of $M$,

$$
M=\frac{1}{\Delta}\left(\begin{array}{ll}
m_{11} & m_{12} \\
m_{21} & m_{22}
\end{array}\right)
$$

where

$$
\begin{gathered}
m_{11}=\lambda_{1} \psi_{1}(x, y, t) \psi_{1}^{*}(x, y,-t)-\lambda_{1}^{*} \psi_{2}(x, y, t) \psi_{2}^{*}(x, y,-t), \\
m_{12}=\left(\lambda_{1}+\lambda_{1}^{*}\right) \psi_{1}(x, y, t) \psi_{2}^{*}(x, y,-t), \\
m_{21}=\left(\lambda_{1}-\lambda_{2}\right) \psi_{2}(x, y, t) \psi_{1}^{*}(x, y,-t), \\
m_{22}=\lambda_{1} \psi_{2}(x, y, t) \psi_{2}^{*}(x, y,-t)-\lambda_{1}^{*} \psi_{1}(x, y, t) \psi_{1}^{*}(x, y,-t), \\
\Delta=\psi_{1} \psi_{1}^{*}(x, y,-t)-\psi_{2} \psi_{2}^{*}(x, y,-t) .
\end{gathered}
$$

So, the new solutions are written as

$$
q^{[1]}(x, y, t)=q(x, y, t)-\frac{2 i\left(\lambda_{1}+\lambda_{1}^{*}\right) \psi_{1}(x, y, t) \psi_{2}^{*}(x, y,-t)}{\Delta},
$$




\section{Exact solutions}

$$
v^{[1]}(x, y, t)=v(x, y, t)+4 i\left(\frac{\lambda_{1} \psi_{1}(x, y, t) \psi_{1}^{*}(x, y,-t)-\lambda_{1}^{*} \psi_{2}(x, y, t) \psi_{2}^{*}(x, y,-t)}{\Delta}\right)_{y} .
$$

We obtain another type of solution for the reverse-space two-dimensional NLS equations (1)-(2) by taking the seed solutions as $q=0, v=0$. Then the corresponding associated linear system takes the form

$$
\begin{aligned}
& \Psi_{1 x}=-i \lambda \Psi_{1}, \\
& \Psi_{2 x}=i \lambda \Psi_{2}, \\
& \Psi_{1 t}=2 \lambda \Psi_{1 y}, \\
& \Psi_{2 t}=2 \lambda \Psi_{2 y} .
\end{aligned}
$$

This system (21)-(24) admits the following exact solutions

$$
\begin{aligned}
& \Psi_{1}=e^{-i \lambda_{1} x+i \mu_{1} y+2 i \lambda_{1} \mu_{1} t_{1}}, \\
& \Psi_{2}=e^{i \lambda_{1} x-i \mu_{1} y-2 i \lambda_{1} \mu_{1} t},
\end{aligned}
$$

where $\lambda_{1}=a+b i, \mu_{1}=c+i d$ and $a, b, c, d$ are real constants. After substitution (25)-(26) in (19)-(20) the exact solutions for the two-dimensional nonlocal nonlinear Schrodinger equation are written as

$$
\begin{aligned}
& q^{[1]}(x, y, t)=-\frac{4 a i e^{i\left(\theta_{1}-\theta_{2}\right)+\left(\chi_{1}-\chi_{2}\right)}}{e^{i\left(\theta_{1}+\theta_{2}\right)+\left(\chi_{1}+\chi_{2}\right)}-e^{-i\left(\theta_{1}+\theta_{2}\right)-\left(\chi_{1}+\chi_{2}\right)},} \\
& v^{[1]}=-4 b\left(\frac{e^{i\left(\theta_{1}+\theta_{2}\right)+\left(\chi_{1}+\chi_{2}\right)}+e^{-i\left(\theta_{1}+\theta_{2}\right)-\left(\chi_{1}+\chi_{2}\right)}}{e^{i\left(\theta_{1}+\theta_{2}\right)+\left(\chi_{1}+\chi_{2}\right)}-e^{-i\left(\theta_{1}+\theta_{2}\right)-\left(\chi_{1}+\chi_{2}\right)}}\right)_{y},
\end{aligned}
$$

where

$$
\begin{gathered}
\theta_{1}=-a x+c y+2 t(a c-b d), \chi_{1}=b x-d y-2 t(b c+a d), \\
\theta_{2}=a x-c y+2 t(a c-b d), \chi_{2}=b x-d y+2 t(b c+a d) .
\end{gathered}
$$

The graphical representation of solutions (27) and (28) is presented in Figure 1 and Figure 2.

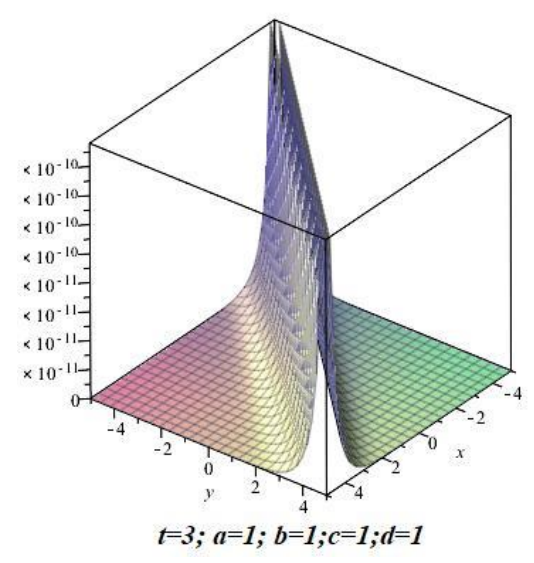

Figure 1. Exact solution $q^{[1]}$ the two-dimensional nonlocal NLS equation (1)-(2)

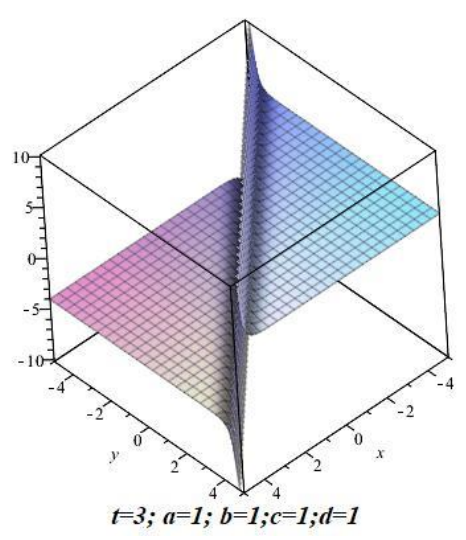

Figure 2. Exact solution $v^{[1]}$ the two-dimensional nonlocal NLS equation (1)-(2) 


\section{Conclusion}

In this paper, we proposed the two-dimensional nonlocal NLS equationwhere the nonlocality consists of reverse time fields. We presented a Lax pair formulation for this equation. By constructing the Darboux transformation, we obtained the exact solutions. The figure of obtained solutions are presented. Using our approach one can find also other kind solutions of two-dimensional nonlocal NLS equation.

The research work was prepared with the financial support of the Committee of Science of the Ministry of Education and Science of the Republic of Kazakhstan, IRN project AP08956932.

References:

1 Yesmakhanova K., Nugmanova G., Shaikhova G.N., Bekova G., Myrzakulov R. Coupled dispersionless and generalized Heisenberg ferromagnet equations with self-consistent sources. Geometry and equivalence. International Journal of Geometric Methods in Modern Physics, V.17, N 7. 2050104 (1-19). (In English)

2 Chulakova A.M., Shajhova G.N., Syzdykova A.M.(2017) Tort komponentti syzykty emes shredinger tendeuler zhujesinin solitondy sheshimderi [Soliton solutions of four-component nonlinear Schrodinger systems of equations] Vestnik KazNPU im Abaja № 3 (59), 141-146. (In Kazakh)

3 Ablovic M., Sigur H.(1987) Solitony i metod obratnoj zadachi [Solitons and methods of the task].M.Mir,479. (In Russian)

4 Ablowitz M., Segur H. Solitons and the Inverse Scattering Transform // SIAM, Philadelphia, 1981. (In English)

5 Kurbangalieva A.K., Shajhova G.N., Syzdykova A.M. (2017) Eki komponentti kompleksti modifikacijalanzan Korteveg-de Friz tȩ̧deuinin nakty solitondyk sheshimderi [Real solitoneal solutions of the Frisian equation in a twocomponent complex modified Corteveg]. Vestnik KazNPU im Abaja № 2 (58), 178-185. (In Kazakh)

6 Matveev V.B., Salle M.A. (1991) Darboux transformations and solitons. Springer-Verlag, Berlin-Heidelberg. (In English)

7 Yesmakanova K R, Shaikhova G.N, Bekova G.T, Myrzakulova Zh.R. (2016) Determinant Representation of Darboux transformation for the (2+1)-Dimensional Schrodinger-Maxwell-Bloch Equation. Advances in Intelligent Systems and Computing, 183-198. (In English)

8 Fokas A.S., Ablowitz M.J. On a method of solution for a class of multidimensional nonlinear evolution equations. Phys. Rev. Lett, 51. (In English)

9 Mark J. Ablowitzl and Ziad H. (2013) MusslimaniIntegrable Nonlocal Nonlinear Schrodinger Equation. Physical review letters prl 110, 064105 (1-5). (In English)

10 AblowitzM., Musslimani Z. (2016) Inverse scattering transform for the integrable nonlocal nonlinear Schrodinger Equation. Nonlinearity, 915-946. (In English)

11 Ablowitz M.,Musslimani Z. (2013) Integrable Nonlocal Nonlinear Schrodinger Equation, Phys. Rev. Lett., 064105(5). (In English)

12 Abdullaev F.K., Kartashov Y.V., Konotop V.V., Zezyulin D.A (2011) Solitons in PT-symmetric nonlinear lattices. Phys. Rev. A 83 -P.041805. (In English)

13 Nazarbek Zh., Yersultanova Z.S., Shaikhova G.N. (2019) Exact solutions of the (2+1)-dimensional nonlocal nonlinear Schrodinger equation.Vestnik KazNPU im. Abaja. Serija Fiziko-matematicheskie nauki. №2 (66),85-88. (In English)

14 Bachtiyarkyzy Zh., Shaikhova G.S., Shaikhova G.N. (2018) Exact solutions of the nonlocal complex modified Korteweg-de Vries system of equations. Vestnik ENU im. L.N. Gumileva. Serija Fizika. Astronomija, №4 (125), 34-39. (In English) 